\title{
ACCEPTABILITY OF K12 SENIOR HigH SCHOOL Students ACAdemic Performance MONITORING SySTEM FOR PRIVATE INSTITUTIONS WITH DECISION SUPPORT SYSTEM
}

\author{
Dr. Winston G. Domingo, Dr. Erwin N. Lardizabal \\ and Sheena Marie V. Toledo \\ College of Information Technology and Engineering, Cagayan Valley \\ Computer and Information Technology College, Philippines
}

\begin{abstract}
The K to 12 Basic Education program uses standards and a competency-based grading system. These are found in the curriculum guides. All grades will be based on the weighted raw score of the learners' summative assessments. Senior High School Students have been graded on three categories the written work, performance tasks, and quarterly assessments. Technology plays a substantial role in helping teachers in the progress, communication, application, and grading of assessment tasks. The correlational aspect aims to establish the degree to which the variables of on the level of compliance of the developed application affects and influences the level of acceptance of the system as perceived by the respondents. From the level of acceptance of the system when it comes to its performance efficiency is directly affected by the level of compliance of the system in its compatibility and reliability. This means that changes on the identified variables may directly affect the variables on the level of acceptance of the system. The findings of significant difference on the perceptions of the IT expert and the Users on the level of acceptance of the system simply imply that the IT experts and the users does not share similar perceptions on the system. This means that there is a significant difference on the level of acceptance of the system as perceived by the users and the IT experts.
\end{abstract}

\section{KEYWORDS}

K to 12 Basic Education, SHS K12 Level of Acceptance, Performance Efficiency, ISO 25010, K12 SHS Grading System.

\section{INTRODUCTION}

The need for new technologies in the teaching-learning process grows stronger and faster. Technology becomes a time of knowledge providing the complete and unmatched possibility for discovery, exchange of information, communication, and exploration to strengthen the teaching and student learning process. Report grades represent teachers' student evaluations of students' performance. Educators must ensure that grading and reporting always meet the criteria for validity and reliability. And because of their primary communication purpose, teachers must also ensure that grading and reporting are correct, accurate, and fair. ${ }^{[1]}$.

The $\mathrm{K}$ to 12 Basic Education program uses standards and a competency-based grading system. These are found in the curriculum guides. The lowest mark that can appear on the report card is 60 for Quarterly Grades and Final Grades. Learners are graded on written work, performance tasks, and quarterly assessments every quarter. These three are given a specific percentage that 
International Journal on Integrating Technology in Education (IJITE), Vol.10, No.4, December 2021

varies according to the nature of the learning. ${ }^{[2] .}$ Technology plays a substantial role in helping teachers in the development, communication, implementation, and grading of assessment tasks. [3]

The researchers want to assess the acceptability of a developed computerized grading system with a decision support system assessed by the IT Experts and End Users. To determine the significant differences in the results as assessed by the IT Experts and End Users.

\subsection{Research Paradigm}

This part of the study is about the research paradigm. The proposed study bore three major components: Input, Process, and Output.

INPUT

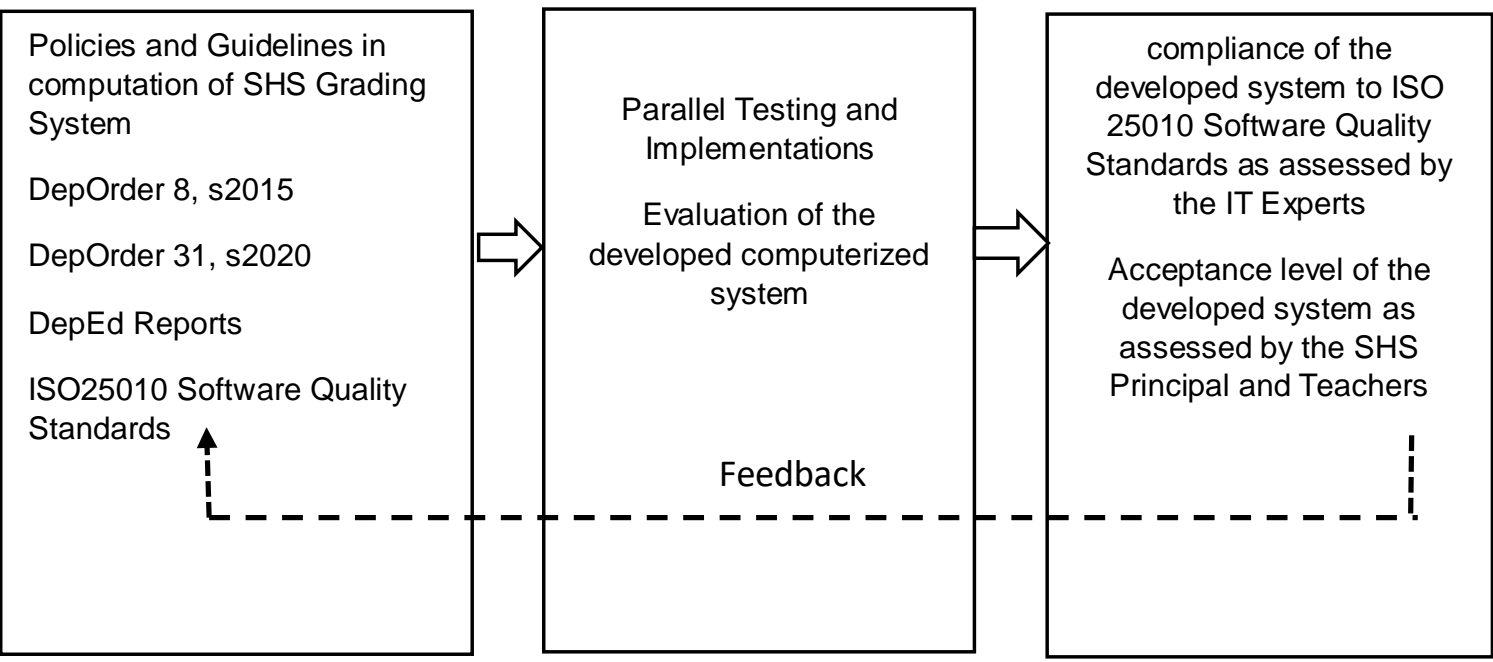

Figure 1. Research Paradigm

Fig. 1 Presents the paradigm of the study. Input includes the problem encountered in manual recording, policies, and guidelines in the computation of SHS Grading System, DepEd Order No. 8, s. 2015 and DepEd Reports. The process includes parallel testing and implementations, and the evaluation of the developed computerized system. The direct goal of this study is to determine the level of compliance of the K12 Senior High School Students Academic Performance Monitoring System for Private Institutions with Decision Support System as assessed by the IT Experts and End Users, using the ISO 25010 Software Quality Standards.

\subsection{Statement of the Problem}

1. What is the level of compliance of the developed computerized system to ISO 25010 Software Quality Standards as assessed by the IT Expert in terms of:

\footnotetext{
Functional sustainability;

$>$ Performance efficiency;

$>$ Compatibility;

> Usability;

$>$ Reliability;

$>$ Maintainability;

$>$ Portability and
} 
International Journal on Integrating Technology in Education (IJITE), Vol.10, No.4, December 2021

Security.

2. What is the extent acceptance level of the developed system as assessed by the principal and senior high school teachers in terms of:

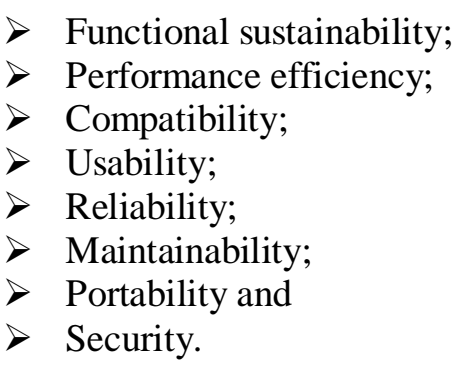

3. Is there a significant relationship between the compliance of the developed application to ISO 25010 Software Quality Standards and the acceptance level of the system as perceived by IT Expert and Users?

4. Is there a significant difference on the perceptions of the IT expert and the Users on the level of acceptance of the system?

\subsection{Hypothesis}

There is no significant relationship between the compliance of the developed application to ISO 25010 Software Quality Standards and the acceptance level of the system as perceived by IT Expert and Users.

\section{METHODS}

\subsection{Research Design}

This study used a descriptive - correlational research design and system development methods. The descriptive method was used to determine the present status and condition of the Senior high school grading system to describe and understand the present environment. The correlational aspect aims to establish the degree to which the variables of on the level of compliance of the developed application affects and influences the level of acceptance of the system as perceived by the respondents. Environment analysis and need analysis were done on the adopted grading system of senior high school in this study. This is to ensure that the phases in system development are done in the software building process. The Agile methodology of SDLC was adapted from the business understanding and requirements elicitation phase to testing the developed computerized grading system for senior high school students. 


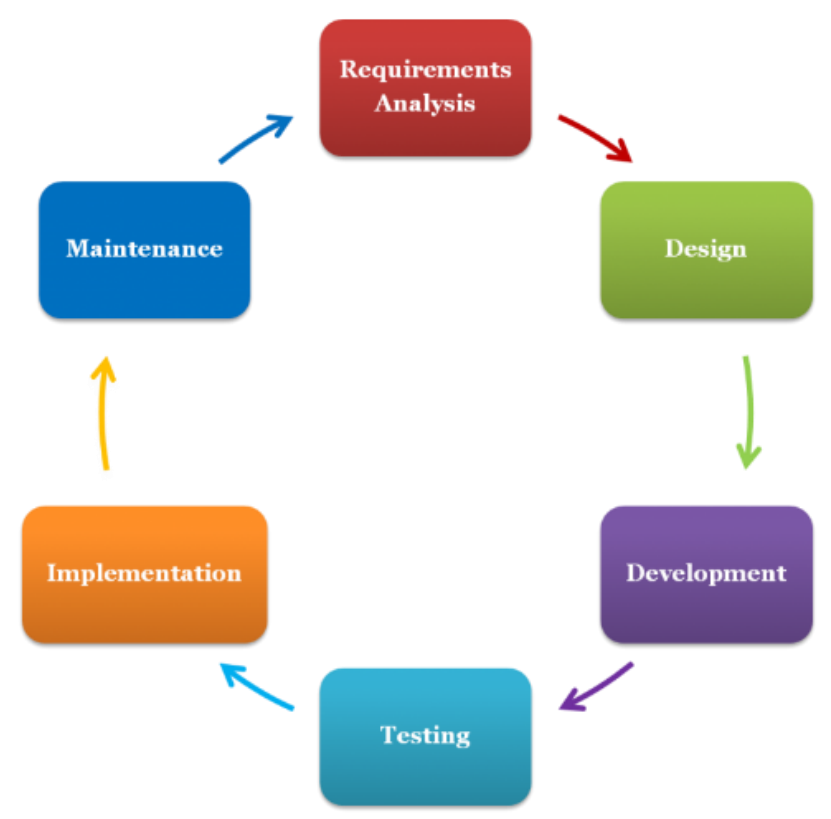

Figure 2. Agile Iterative Model

Fig. 2 Agile Iterative Model was adopted to guide the development of the computerized grading system for senior high ${ }^{[4]}$. Every iteration in system development involves the following process:

Requirement Analysis. In this procedure, the researcher accompanied a series of interviews with the Senior High School Principal and Teachers who typically administered and monitored the whole actions of the grading system. All the gathered data and information was studied by the researchers to come up with appropriate inputs in designing and developing the computerized grading system for senior high school students.

Design. The researcher chose the appropriate programming software, database, and hardware with which the developed system could be compatible. The researcher constantly coordinated with the users and top management on the features that are suitable for their needs.

Development. The activities involved here are the designing and coding of the user interface. During the development, there were a series of laboratory testing that was conducted in the different modules of the system. Compatibility testing was done and constant coordination with the users was made to align the users' specifications with the developed system.

Testing. In this procedure, the parallel testing of the developed system was done. The researcher collected comments from the testing teams which served as the basis for the modification and redesign of the system.

Implementation. The researcher executed the system in the Department of Senior High School at CVCITC, Santiago City. The system was installed and used. During the implementation phase, a series of training was made to the Principal and Teachers. Calibration and alignment of expectations of the users with the developed system were done.

Maintenance. In this process, the monitoring of the implementation and documentation of the use of the system was done. The problems and challenges encountered by the users were closely recorded and reported. The errors and bugs encountered by the users including suggestions on better features were documented and fixed. 


\subsection{Respondents}

There were 16 respondents of the study selected using purposive sampling to determine the practices and policies of the senior high school department. They provided inputs on the Users' specifications such as their needs and challenges. They were the ones directly involved in the operations of the senior high school grading system and the best personnel to get the needed inputs for consideration in the design process of the developed system.

Table 2. Respondents of the Study

\begin{tabular}{|l|c|}
\hline \multicolumn{1}{|c|}{ Nature of Work } & No. of Respondents \\
\hline Principal & 1 \\
\hline SHS Teachers & 10 \\
\hline IT Experts Total & $\mathbf{1 6}$ \\
\hline
\end{tabular}

The senior high school principal provided the top management perspective on how the senior high school grading system. How the computerized grading system will help in monitoring grades and preparation of reports using computerization? The senior high school teachers are considered as the main users of the system. They will be the ones to use the system, by recording the class records in the system. They also identified the reports that they needed from the developed system as part of the semester and annual reports. As users, they have expressed their report requirements and helped in the evaluation of the developed system. IT Experts will evaluate the performance of the system in terms of Functional sustainability; Performance efficiency; Compatibility; Usability; Reliability and Security.

\subsection{Instrument}

This study made use of a focus group discussion, observation checklist, interview guide, and documentary analysis.

\subsection{Data Gathering Procedure}

The researcher secured approval from School Administration and Senior High School Department, CVCITC Santiago City. The study also underwent an ethics review to ensure that there would be no violation of the Privacy Act. The researcher gathered data through a series of interviews. Focus Group Discussion (FGD) was also conducted with the Principal and Senior High School Teachers. The results were the basis of the researchers in the design and development of the system. The researchers conducted form and report evaluation as part of the data gathering procedure to have a deeper understanding of the current grading system. The developed system was tested and used by the users (Teachers and Principals) of the system and they were also involved in the evaluation of the interface of the system. Their recommendations were considered in the development of computerizing the grading system for senior high school.

\subsection{Statistical Treatment of Data}

The data collected were tabulated, analyzed, interpreted, and summarized using both descriptive and inferential statistics. Frequency Count and Percentage Distribution were used to describe the demographic profile of the participants, Mean Score was used to analyze the average rating of the IT experts and End Users concerning the compliance of the application that was developed and 
International Journal on Integrating Technology in Education (IJITE), Vol.10, No.4, December 2021

implemented in this study concerning the ISO 25010 software quality standard. Correlational statistics is used to establish the significant relationship between the variables.

\section{Results}

\section{The level of compliance of the developed system to ISO 25010 Software Quality Standards as assessed by the IT Expert}

Table 4: Level of compliance of the developed system to ISO 25010 Software Quality Standards as assessed by the IT Expert

\begin{tabular}{|c|c|c|}
\hline $\begin{array}{l}\text { ISO 25010 Software Quality } \\
\text { Standards. }\end{array}$ & MEAN & Descriptive Rating \\
\hline 1) Functional Suitability & 3.87 & Highly Compliant \\
\hline 2) Performance Efficiency & 3.60 & Highly Compliant \\
\hline 3) Compatibility & 4.00 & Highly Compliant \\
\hline 4) Usability & 3.57 & Highly Compliant \\
\hline 5) Reliability & 3.50 & Highly Compliant \\
\hline 6) Security & 3.68 & Highly Compliant \\
\hline 7) Maintainability & 3.72 & Highly Compliant \\
\hline 8) Portability & 3.80 & Highly Compliant \\
\hline GRAND MEAN & 3.72 & Highly Compliant \\
\hline
\end{tabular}

Table 4 presents the result of the level of compliance of the developed system to ISO 25010 Software Quality Standards as assessed by the IT Expert that obtained the Grand mean of 3.72 with the descriptive rating of highly compliant. The indicator of ISO 25010 Software Quality Standards such as functional sustainability, performance efficiency, compatibility, usability, reliability, security, maintainability, and portability got the descriptive rating of highly compliant. Therefore, it can be inferred that the developed application was highly approved and accepted by the IT experts.

2. The extent of acceptance level of the developed system as assessed by the principal and senior high school teachers

Table 5: The extent of acceptance level of the developed system as assessed by the principal and senior high school teachers

\begin{tabular}{|l|c|l|}
\hline \multicolumn{1}{|c|}{$\begin{array}{c}\text { ISO 25010 Software Quality } \\
\text { Standards. }\end{array}$} & MEAN & \multicolumn{1}{c|}{ Descriptive Rating } \\
\hline 1) Functional Suitability & 3.76 & Highly Accepted \\
\hline 2) Performance Efficiency & 3.70 & Highly Accepted \\
\hline 3) Compatibility & 3.50 & Highly Accepted \\
\hline 4) Usability & 3.65 & Highly Accepted \\
\hline 5) Reliability & 3.66 & Highly Accepted \\
\hline 6) Security & 3.60 & Highly Accepted \\
\hline 7) Maintainability & 3.56 & Highly Accepted \\
\hline 8) Portability GRAND MEAN & 3.64 & Highly Accepted \\
\hline \multicolumn{1}{|c|}{$\mathbf{3 . 6 3}$} & Highly Accepted \\
\hline
\end{tabular}

Table 5 presents the result to the extent of acceptance level of the developed system to ISO 25010 Software Quality Standards as assessed by the principal and senior high school teachers that obtained the Grand mean of 3.63 with the descriptive rating of highly accepted. The indicator of 
International Journal on Integrating Technology in Education (IJITE), Vol.10, No.4, December 2021

ISO 25010 Software Quality Standards such as functional sustainability, performance efficiency, compatibility, usability, reliability, security, maintainability, and portability got the descriptive rating of highly accepted. Therefore, it can be inferred that the developed application was highly approved and accepted by the principal and senior high school teachers. Thus, it results in the full implementation of the developed system to be used by the SHS faculty and SHS Principal. Comply with all the requirements, policies, and guidelines of Department of Education Order No. 8, s. 2015, Policy on Classroom Assessment for the K to 12 Basic Education Program ${ }^{[5]}$ and Department of Education Order No. 36, s. 2016, Policy Guidelines on Awards and Recognition for the K to 12 Basic Education Program ${ }^{[6]}$

\section{Test of relationship between and among the variables of the level of compliance and the level of acceptability of the system.}

Table 6. Test of relationship between and among the variables of the level of compliance and the level of acceptability of the system

\begin{tabular}{|c|c|c|c|c|c|c|c|c|c|}
\hline \multicolumn{10}{|c|}{ Level of Acceptance } \\
\hline \multicolumn{2}{|c|}{ Level of Compliance } & \multirow{2}{*}{$\begin{array}{c}\begin{array}{c}\text { Functio } \\
\text { nality }\end{array} \\
.000^{*}\end{array}$} & \multirow{2}{*}{$\begin{array}{c}\begin{array}{c}\text { Performa } \\
\text { nce } \\
\text { Efficienc } \\
y\end{array} \\
.167\end{array}$} & \multirow{2}{*}{$\begin{array}{c}\text { Compatib } \\
\text { ility } \\
-.617\end{array}$} & \multirow{2}{*}{$\begin{array}{c}\text { Usabil } \\
\text { ity } \\
-.408\end{array}$} & \multirow{2}{*}{$\begin{array}{c}\text { Reliabi } \\
\text { lity } \\
-.816\end{array}$} & \multirow{2}{*}{$\begin{array}{c}\text { Securit } \\
\mathrm{y} \\
\\
-.289\end{array}$} & \multirow{2}{*}{$\begin{array}{c}\text { Maintai } \\
\text { nability } \\
-.136\end{array}$} & \multirow{2}{*}{$\begin{array}{c}\text { Portabilit } \\
\text { y } \\
-.617\end{array}$} \\
\hline $\begin{array}{c}\text { Functio } \\
\text { nality }\end{array}$ & $\begin{array}{l}\text { Correlation } \\
\text { Coefficient }\end{array}$ & & & & & & & & \\
\hline & Sig. (2-tailed) & 1.000 & .739 & .197 & .374 & .076 & .543 & .767 & .197 \\
\hline \multirow{3}{*}{$\begin{array}{l}\text { Perform } \\
\text { ance } \\
\text { Efficien } \\
\text { cy }\end{array}$} & $\begin{array}{l}\text { Correlation } \\
\text { Coefficient }\end{array}$ & -.802 & -.722 & -.802 & -.589 & -.589 & $-1.000^{*}$ & -.354 & -.802 \\
\hline & & & & & & & & & \\
\hline & Sig. (2-tailed) & .078 & .128 & .078 & .179 & .179 & .000 & .420 & .078 \\
\hline \multirow[t]{2}{*}{$\begin{array}{c}\text { Compati } \\
\text { bility }\end{array}$} & $\begin{array}{l}\text { Correlation } \\
\text { Coefficient }\end{array}$ & 1.000 & $.693^{*}$ & .279 & .322 & .263 & .515 & .322 & .393 \\
\hline & Sig. (2-tailed) & .000 & .019 & .336 & .251 & .347 & .062 & .251 & .168 \\
\hline \multirow[t]{2}{*}{$\begin{array}{c}\text { Usabilit } \\
\mathrm{y}\end{array}$} & $\begin{array}{l}\text { Correlation } \\
\text { Coefficient }\end{array}$ & $.000 *$ & .144 & -.802 & -.825 & -.825 & -.375 & -.589 & -.802 \\
\hline & Sig. (2-tailed) & 1.000 & .761 & .078 & .060 & .060 & .407 & .179 & .078 \\
\hline \multirow[t]{2}{*}{$\begin{array}{c}\text { Reliabil } \\
\text { ity }\end{array}$} & $\begin{array}{l}\text { Correlation } \\
\text { Coefficient } \\
\end{array}$ & -.120 & $.000 *$ & -.837 & -.738 & $-.949^{*}$ & -.447 & -.527 & -.837 \\
\hline & Sig. (2-tailed) & .782 & 1.000 & .052 & .077 & $.023 * *$ & .296 & .207 & .052 \\
\hline \multirow[t]{2}{*}{ Security } & $\begin{array}{l}\text { Correlation } \\
\text { Coefficient } \\
\end{array}$ & -.535 & -.433 & -.802 & -.589 & -.589 & -.875 & -.354 & -.802 \\
\hline & Sig. (2-tailed) & .240 & .361 & .078 & .179 & .179 & .053 & .420 & .078 \\
\hline \multirow[t]{2}{*}{$\begin{array}{l}\text { Maintai } \\
\text { nability }\end{array}$} & $\begin{array}{l}\text { Correlation } \\
\text { Coefficient } \\
\end{array}$ & $.000 *$ & .144 & -.802 & -.825 & -.825 & -.375 & -.589 & -.802 \\
\hline & Sig. (2-tailed) & 1.000 & .761 & .078 & .060 & .060 & .407 & .179 & .078 \\
\hline \multirow[t]{2}{*}{$\begin{array}{l}\text { Portabil } \\
\text { ity }\end{array}$} & $\begin{array}{l}\text { Correlation } \\
\text { Coefficient }\end{array}$ & .378 & .612 & -.378 & -.500 & -.500 & .177 & -.500 & -.378 \\
\hline & Sig. (2-tailed) & .429 & .221 & .429 & .277 & .277 & .709 & .277 & .429 \\
\hline
\end{tabular}

The table above shows the test of relationship on the level of compliance of the system to the level of acceptance of the users. It can be gleaned above that compliance on the ISO standards for functionality, maintainability and usability of the system affects the level of acceptance of the system in terms of its functionality. Further, the level of acceptance of the system when it comes 
International Journal on Integrating Technology in Education (IJITE), Vol.10, No.4, December 2021

to its performance efficiency is directly affected by the level of compliance of the system in its compatibility and reliability. This means that changes on the identified variables may directly affect the variables on the level of acceptance of the system.

\section{Significant difference on the perceptions of the IT expert and the Users on the level of acceptance of the system}

Table 7. Test of difference between the perceptions of the IT Experts and the Users on the level of acceptance of the system

\begin{tabular}{|c|c|c|c|c|c|}
\hline $\begin{array}{c}\text { GROUPS } \\
\text { COMPARED }\end{array}$ & MEAN & $\begin{array}{c}\text { STD. } \\
\text { DEVIATION }\end{array}$ & $\begin{array}{c}\text { P- } \\
\text { VALUE }\end{array}$ & INTERPRETATION & DECISION \\
\hline IT EXPERTS & 3.72 & .16654 & \multirow{2}{*}{$.000^{*}$} & \multirow{2}{*}{ SIGNIFICANT } & REJECT HO \\
\cline { 1 - 3 } & 3.63 & .08088 & &
\end{tabular}

Results on the table above presents the test of difference between the perceptions of the IT Experts and the Users on the level of acceptance of the system. The findings simply imply that the IT experts and the users does not share similar perceptions on the system as shown on the pvalue which is less that the significance level of .05 . This means that there is a significant difference on the level of acceptance of the system as perceived by the users and the IT experts. Hence, the null hypothesis is rejected.

\section{CONClusion}

From the above findings, the researcher concluded that the developed application was highly approved and accepted by the IT experts. Also, the developed application was highly approved and accepted by the principal and senior high school teachers. Comply with all the requirements, policies, and guidelines of Department of Education Order No. 8, s. 2015, Policy on Classroom Assessment for the K to 12 Basic Education Program. From the level of acceptance of the system when it comes to its performance efficiency is directly affected by the level of compliance of the system in its compatibility and reliability. This means that changes on the identified variables may directly affect the variables on the level of acceptance of the system. The findings of significant difference on the perceptions of the IT expert and the Users on the level of acceptance of the system simply imply that the IT experts and the users does not share similar perceptions on the system. This means that there is a significant difference on the level of acceptance of the system as perceived by the users and the IT experts

\section{ACKNOWLEDGMENT}

The researcher would like to extend their warmest gratitude to those people who extend their hand in making this research possible; CVCITC Administration, SHS Department, Office of the SHS Principal, SHS Faculty and Teachers, MIS Office, families, and friends.

\section{REFERENCES}

[1] Muñoz, M. A., \& Guskey, T. R. (2015). Standards-based grading and reporting will improve education. Phi Delta Kappan, 96(7), 64-68.

[2] Department of Education Order No. 8, s. 2015, Policy on Classroom Assessment for the K to 12 Basic Education Program, Retrieved from http://www.deped.gov.ph/wpcontent/uploads/2015/04/DO_s2015_08.pdf

[3] Department of Education Order No. 31, s. 2020, The Interim Guidelines for Assessment and Grading in light of the Basic Education Learning Continuity Plan, Retrieved from https://www.deped.gov.ph/wp-content/uploads/2020/10/DO_s2020_031.pdf 
International Journal on Integrating Technology in Education (IJITE), Vol.10, No.4, December 2021

[4[ Harinath Mallepally (2016), Agile Iterative Model, Retrieved from http://www.agilemethod.net/p/waterfall.html

[5] ISO25010 Software Quality Standards, Retrieved from https://iso25000.com/index.php/en/iso-25000standards/iso-25010

[6] Department of Education Order No. 36, s. 2016, Policy Guidelines on Awards and Recognition for the K to 12 Basic Education Program, Retrieved from https://www.deped.gov.ph/2016/06/07/do-36-s2016-policy-guidelines-on-awards-and-recognition-for-the-k-to12-basic-education-program-2/

\section{AUTHORS}

\section{Dr. WINSTON G. DOMINGO}

Dean of the College of Information Technology and Engineering of Cagayan Valley Computer and Information Technology College.

\section{Dr. ERWIN N. LARDIZABAL}

BSIT Program Chairperson of Cagayan Valley Computer and Information Technology College.

\section{SHEENA MARIE V. TOLEDO, MSIT}

Faculty of College of Information Technology and Engineering, Cagayan Valley Computer and Information Technology College.
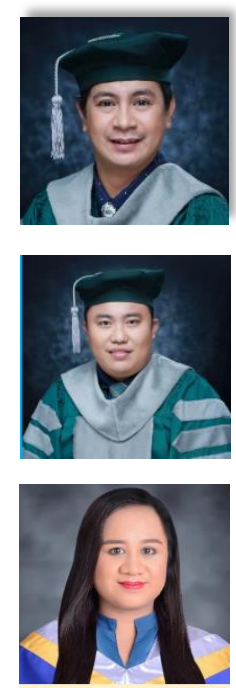